\title{
The Southern African Development Community (SADC) and its Tribunal: Reflexions on a Regional Economic Communities' Potential Impact on Human Rights Protection
}

\author{
By Oliver C. Ruppel, Windhoek*
}

\section{Introduction}

It was in the 1960s, when the United Nations Economic Commission for Africa (UNECA) encouraged African states to incorporate single economies into sub-regional systems with the ultimate objective of creating a single economic union on the African continent. In order to realise this aim, the Organisation of African Unity (OAU, predecessor of the African Union, AU) identified the need to enhance regional integration within the organisation, recognising that each country on its own would have little chance of, inter alia, attracting adequate financial transfers and the technology needed for increased economic development. ${ }^{1}$ Africa has, since then, taken various steps towards enhancing the process of economic and political integration on the continent. ${ }^{2}$ The road has been paved by several decisions and declarations relating to regional economic and political integration, especially by the Abuja Treaty, realising the establishment of the African Economic Community, the African Union's economic and umbrella institution for Regional Economic Communities (RECs). The Abuja Treaty was adopted in June 1991, and came into force in 1994. Since then, 52 out of the 53 AU member states have signed the Treaty, ${ }^{3}$ while 49 have ratified it. 4

Oliver C. Ruppel, Dr. jur., LL.M. (Stellenbosch); Director, Human Rights and Documentation Centre, Windhoek and Senior Lecturer in Law, Faculty of Law, University of Namibia. Email: ruppel@ mweb.com.na, or: ocruppel@unam.na.

1 For the process of regional integration within SADC, see D. Hansohm / R.. Shilimela, Progress in economic integration within SADC, in: A. Bösl, W. Breytenbach, T. Hartzenberg, C. McCarthy, K. Schade (eds.), Monitoring regional integration in southern Africa: Yearbook 6. Stellenbosch 2006, p. 7.

2 On various initiatives by African leaders to carry out the integration process in Africa, cf. $R$. $N$. Kouassi, The itinerary of the African integration process: An overview of the historical landmarks, African Integration Review 1 (2007), p. 2.

Eritrea has not yet signed the Abuja Treaty; cf. status list of countries regarding the Abuja Treaty, available at http://www.africa-union.org/root/au/Documents/Treaties/List/Treaty\%20Establishing $\% 20$ the\%20African\%20Economic\%20Community.pdf.

4 The countries which have signed but not yet ratified the Abuja Treaty are Djibouti, Madagascar and Somalia; cf. status list of countries regarding the Abuja Treaty, available at http://www.africaunion.org/root/au/Documents/Treaties/List/Treaty\%20Establishing\%20the\%20African\%20Econo mic\%20Community.pdf. 
Meanwhile, several RECs have been established on the continent. ${ }^{5}$ At the seventh ordinary session of the AU's Assembly of Heads of State and Government in Banjul, The Gambia, in July 2006, the AU officially recognised eight such communities: ${ }^{6}$ The Arab Maghreb Union (AMU); The Community of Sahel-Saharan States (CEN-SAD); The Common Market for Eastern and Southern Africa (COMESA); The East African Community (EAC); The Economic Community of Central African States (ECCAS); The Economic Community of West African States (ECOWAS); The Intergovernmental Authority on Development (IGAD), and The Southern African Development Community (SADC). Except for the Sahrawi Arab Democratic Republic ${ }^{7}$, all AU member states are affiliated to one or more of these RECs.

Assuming that the responsibility for upholding human rights and fundamental freedoms rests primarily on the individual states themselves, the question may arise as to the role that RECs play when it comes to the protection of human rights, and whether or not - and if so, how - RECs can function as guardians of human rights. Although states might be primarily responsible for upholding human rights because they are answerable to their citizens, the international community, and the UN if they fail to respect human rights in their countries, ${ }^{8}$ the influence of RECs should not be underestimated. Taking the example of the Southern African Development Community and its Tribunal, this article highlights the special role of RECs for the protection of human rights.

The number of RECs varies depending on the definition of $R E C$ and on whether specific subgroups or monetary unions such as the Central African Economic and Monetary Community or certain free trade areas such as the Euro-Mediterranean Free Trade Area (with Egypt, Morocco and Tunisia, and states around the Mediterranean) are counted or not. Viljoen states that at least 14 sub-regional integration groupings exist in Africa. See $F$. Viljoen, International human rights law in Africa, Oxford 2007, p. 488.

See the decision relating to the recognition of RECs, namely (Assembly/AU/Dec.112 (VII) Doc. EX.CL/278 (IX)); text in French available at http://www.africa-union.org/Official_documents/ Assemblee\%20fr/ASS06b.pdf; last accessed 22 December 2008.

Due to the controversies regarding the Sahrawi Arab Democratic Republic, Morocco withdrew from the OAU in protest in 1984 and, since South Africa's admittance in 1994, remains the only African nation not within what is now the African Union (AU). Although the Sahrawi Arab Democratic Republic was a full member of the OAU since 1984 and remains a member of the $\mathrm{AU}$, the republic is not generally recognised as a sovereign state. While most African states have recognised the republic (e.g. Namibia and South Africa), several others have withdrawn their former recognition (e.g. Cape Verde, the Seychelles), and some have temporarily frozen diplomatic relations (e.g. Costa Rica, Ghana), pending the outcome of a respective UN referendum which would allow the people of Western Sahara to decide the territory's future status. The republic has no representation at the United Nations.

Cf. European Commission, Communication from the Commission to the Council and the European Parliament: The European Union's role in promoting human rights and democratisation in third world countries. Brussels: EC, COM (2001), p. 252. 


\section{Regional economic communities and the protection of human rights}

At first glance it appears that the promotion and protection of human rights is not within the RECs' focal range. However, human-rights-related matters play a vital role within the RECs' legal framework as well as in their daily practice, as many have implemented certain provisions in their mandate that have an impact on human rights and good governance. RECs have, to some extent - be it explicitly or implied - incorporated human rights into their treaties. In most cases, a general tribute to recognising and protecting human rights can be found in the basic legal concepts underpinning RECs. Some even cover specific human rights issues, such as HIV and AIDS, equality and gender issues, humanitarian assistance and refugees, and children's rights, to name but a few.

The reasons for integrating human rights into the structure of RECs are manifold. One reason certainly is that states have committed themselves to respecting human rights by acceding to specific human rights treaties, conventions or declarations on the international, regional and sub-regional level, including the Universal Declaration of Human Rights; the International Covenants on Civil and Political Rights and on Economic, Social and Cultural Rights; the Convention on the Elimination of Racial Discrimination; or the African Charter on Human and Peoples' Rights. The obligations and commitments resulting from such human-rights-related legal instruments are also reflected in the conceptualisation of RECs.

The interrelationship between human rights and economic development has become closer over the past few years due to increasing discussions in the world community on the issue $^{9}$ and can be seen as a two-way relationship insofar as economic development is obliged to respect human rights in a democratic society. Conversely, human rights can be given more effect through economic growth, as one outcome of economic growth is the increasing availability of resources, resulting in the reduction of poverty and a higher standard of living.

Therefore, the promotion of human rights plays an important role in the process of regional integration, as envisaged by the Abuja Treaty as well as by REC constitutive legal instruments. However, the integration process faces many obstacles and challenges, which do also touch on human rights. The fear of losing State autonomy, the fear of losing identity, socio-economic disparity among members, historical disagreement, lack of vision, and unwillingness to share resources are some of the obstacles that present themselves when it comes to regional integration.

Depending on how human rights are incorporated into the RECs legal framework, the sub-regional organisation has a number of options open in respect of enhancing the protec- 
tion of human rights. ${ }^{10}$ Considering that human rights do, to some extent, form part of the RECs community law, decision-making organs and regional community courts can unquestionably contribute towards the promotion and protection of human rights, provided that decisions by regional administrative and judicial institutions are properly enforced at a national level. RECs do therefore have a clear mandate to promote and protect human rights.

\section{The Southern African Development Community - SADC}

SADC was established in Windhoek in 1992 as the successor organisation to the Southern African Development Coordination Conference (SADCC), which was founded in 1980. SADC was established by signature of its constitutive legal instrument, the SADC Treaty. SADC envisages 11

“... a common future, a future in a regional community that will ensure economic well-being, improvement of the standards of living and quality of life, freedom and social justice and peace and security for the peoples of Southern Africa. This shared vision is anchored on the common values and principles and the historical and cultural affinities that exist between the peoples of Southern Africa."

To this end, SADC's objectives include the achievement of development and economic growth; the alleviation of poverty; the enhancement of the standard and quality of life; support of the socially disadvantaged through regional integration; the evolution of common political values, systems and institutions; the promotion and defence of peace and security; and achieving the sustainable utilisation of natural resources and effective protection of the environment. ${ }^{12}$ According to the UN Statistical Division, ${ }^{13}$ SADC counts a total population of more than 245 million, who inhabit a surface area of almost 10 million $\mathrm{km}^{2}$, and a total GDP of over US\$ 432 billion. SADC's headquarters are in Gaborone, Botswana, and the SADC working languages are English, French and Portuguese. The institutions of SADC, provided for in the SADC Treaty, are the Summit of Heads of State or Government; the Organ on Politics, Defence and Security Co-operation; the Council of Ministers; the Integrated Committee of Ministers; the Standing Committee of Officials; the Secretariat; the Tribunal; and SADC National Committees. SADC currently counts 15 states among its members, namely Angola, Botswana, the DRC, Lesotho, Madagascar,

Four options have been outlined by $F$. Viljoen, The realisation of human rights through subregional institutions, African Yearbook of International Law, 7 (1999), p. 208 ff.Viljoen favours the third of the following options: (a) to ignore human rights issues, leaving it to the domestic or regional legal system to redress violations; (b) to use the limited human rights mandate in the relevant organisation's treaty as a basis to cultivate a better human rights environment in the member states concerned; (c) to adopt own sub-regional charters on human rights; or (d) to fully incorporate the African Charter on Human and Peoples' Rights into the sub-regional treaty.

See SADC's Vision, at http://www.sadc.int/.

12 These are some of the SADC objectives laid down in Article 5 of the SADC Treaty.

13

http://unstats.un.org/unsd/default.htm. 
Malawi, Mauritius, Mozambique, Namibia, the Seychelles, ${ }^{14}$ South Africa, Swaziland, Tanzania, Zambia, and Zimbabwe. The Regional Indicative Strategic Development Plan (RISDP) approved by the SADC Summit in 2003, has defined the following targets for regional integration within SADC:

- A Free Trade Area by 2008;

- Completion of negotiations of the SADC Customs Union by 2010;

- Completion of negotiations of the SADC Common Market by 2015;

- SADC Monetary Union and SADC Central Bank by 2016, and

- Launch of a regional currency by 2018.

As a first step towards deeper regional integration, SADC launched the FTA in August 2008 in order to create a larger market, releasing potential for trade, economic development and employment creation. ${ }^{15}$ As various SADC member states are also parties to other RECs, ${ }^{16}$ the Common Market for Eastern and Southern Africa (COMESA), the East African Community (EAC) and SADC have decided to accelerate economic integration of the continent, with the aim of achieving economic growth, reducing poverty and attaining sustainable economic development. To this end, it was resolved that the three RECs should $-17$

“... immediately start working towards a merger into a single REC with the objective of fast[-] tracking the attainment of the African Economic Community."

In the area of trade, customs and economic integration, it was approved that an FTA be established, encompassing the three RECs' member states with the ultimate goal of establishing a single customs union.

The Seychelles was a member of SADC from 1997 to 2004; it rejoined SADC in 2008.

See Section 14, Final Communiqué of the 28th Summit of SADC Heads of State and Government held in Sandton, South Africa, from 16 to 17 August 2008.

SADC members that are simultaneously COMESA members are the DRC, Madagascar, Malawi, Mauritius, the Seychelles, Zambia and Zimbabwe. Burundi, Kenya, Rwanda and Uganda are simultaneously members of EAC and COMESA, while Tanzania is a member of the EAC as well as of SADC. On the specific issue of overlapping memberships, O. C. Ruppel/ F.-X. Bangamwabo, The SADC Tribunal: A Legal Analysis of its Mandate and Role in Regional Integration in: A. Bösl / W. Breytenbach, , Hartzenberg, T., McCarth, C. and Schade, K. (eds.), Monitoring regional integration in southern Africa: Yearbook 8. Stellenbosch [forthcoming].

COMESA-EAC-SADC / Common Market for Eastern and Southern Africa-East African Community-Southern African Development Community, Final Communiqué of the COMESAEAC-SADC Tripartite Summit of Heads of State and Government, held in October 2008 in Kampala, Uganda: Towards a single market - Deepening COMESA-EAC-SADC integration, available at http://about .comesa.int/attachments/078_Final_Communique-Kampala_22_10_08 .pdf. 


\section{Human rights protection within SADC}

It might appear that the promotion and protection of human rights are not SADC top priority as an organisation that furthers socio-economic cooperation and integration as well as political and security cooperation among its 15 southern African member states. However, the protection of human rights plays an essential role in economic development as it has an impact on the investment climate, which in turn contributes to growth, productivity and employment creation, all being essential for sustainable reductions in poverty. A ministerial workshop in 1994 called for the adoption of a SADC Human Rights Commission as well as for a SADC Bill of Rights. In 1996, a SADC Human Rights Charter was drafted, albeit by NGOs of several SADC member states. In the course of establishing the SADC Tribunal in 1997, a panel of legal experts considered the possibility of separate human rights instruments such as a Protocol of Human Rights or a separate Southern African Convention on Human Rights. None of these proposals was realised, however. ${ }^{18}$ Nonetheless, many human-rights-related provisions can be found within SADC's legal framework. The SADC Treaty itself refers to regional integration and to human rights directly or indirectly at several stages. In its Preamble, the Treaty determines, inter alia, to ensure, through common action, the progress and well-being of the people of southern Africa, and recognises the need to involve the people of the SADC region centrally in the process of development and integration, particularly through guaranteeing democratic rights, and observing human rights and the rule of law. The Preamble's contents are given effect within the subsequent provisions of the SADC Treaty. Chapter 3, for example, which deals with principles, objectives, the common agenda and general undertakings, provides that SADC and its member states are to act in accordance with the principles of human rights, democracy and the rule of law. ${ }^{19}$ Moreover, the objectives of $\mathrm{SADC}^{20}$ relate to human rights issues in one way or another. For instance, the objective of alleviating and eventually eradicating poverty contributes towards ensuring, inter alia, a decent standard of living, adequate nutrition, health care and education - all these being human rights. ${ }^{21}$ Other SADC objectives such as the maintenance of democracy, peace, security and stability refer to human rights, as do the sustainable utilisation of natural resources and effective protection of the environment known as third-generation human rights. ${ }^{22}$

For more details on these historical developments, see Viljoen, above Fn. 10, pp. 185 -216.

19

20

Article 4(c), SADC Treaty.

21

Article 5, SADC Treaty.

UNDP/United Nations Development Programme, Human rights and development: Human Development Report, New York 2000.

22

$O$. C. Ruppel, Third-generation human rights and the protection of the environment in Namibia, in: N. Horn, and A. Bösl, (eds.), Human rights and the rule of law in Namibia, Windhoek 2008, p. $101 \mathrm{ff}$. 
Besides the aforementioned provisions and objectives, the SADC legal system offers human rights protection in many legal instruments other than the SADC Treaty. One category of legal documents constitutes the SADC Protocols. The Protocols are instruments by means of which the SADC Treaty is implemented; they have the same legal force as the Treaty itself. A Protocol comes into force after two thirds of SADC member states have ratified it. A Protocol legally binds its signatories after ratification. Most SADC Protocols are either directly or indirectly relevant to human rights. Of specific relevance in terms of human rights are the gender-related instruments within the SADC legal framework. ${ }^{23}$ For example, the Protocol on Gender and Development was signed during the 28th SADC Summit in August 2008. ${ }^{24}$ Recognising that the integration and mainstreaming of gender issues into the SADC legal framework is key to the sustainable development of the SADC region, and taking into account globalisation, human trafficking of women and children, the feminisation of poverty, and violence against women, amongst other things, the Protocol in its 25 Articles expressively address issues such as affirmative action, access to justice, marriage and family rights, gender-based violence, health, HIV and AIDS, and peacebuilding and conflict resolution. The Protocol provides that, by 2015, member states are obliged to enshrine gender equality in their respective constitutions, and that their constitutions state that the provisions enshrining gender equality take precedence over their customary, religious and other laws. ${ }^{25}$

The implementation of the Protocol's provisions is the responsibility of the various SADC member states, ${ }^{26}$ and specific provisions as to monitoring and evaluation are laid down in the Protocol. ${ }^{27}$ The SADC Tribunal is the judicial body that has jurisdiction over disputes relating to this Protocol. ${ }^{28}$ Apart from the SADC Treaty and the SADC Protocols, the REC has other instruments at different levels. The latter are not binding, and do not require ratification by SADC members. With respect to their human rights relevance, such instruments include the Principles and Guidelines Governing Democratic Elections; the Charter of Fundamental and Social Rights in SADC; the Declaration on Agriculture and Food Security; and the Declaration on HIV and AIDS.

The Principles and Guidelines Governing Democratic Elections ${ }^{29}$ are of specific importance for first-generation human rights, which comprise civil and political rights. The

W. Visser / K.G.V.E. Ruppel-Schlichting, Women and custom in Namibia - The legal setting, in: Ruppel, O.C. (ed.), Women and custom in Namibia: Cultural practice versus gender equality?, Windhoek 2008, p. 157.

See Section 16, Final Communiqué of the 28th Summit of SADC Heads of State and Government held in Sandton, South Africa, 16 to 17 August 2008.

Article 4, SADC Protocol on Gender and Development.

Article 14, SADC Protocol.

Article 17, SADC Protocol.

Article 18, SADC Protocol.

29

Referred to hereafter as the Guidelines. 
Guidelines focus on citizens' participation in the decision-making processes and the consolidation of democratic practice and institutions. Besides the basic principles for conducting democratic elections, the Guidelines inter alia provide for SADC Electoral Observation Missions that member states can invite to observe their elections; guidelines on the observation of elections; a code of conduct for election observers; and the rights and duties of a member state holding elections.

The 2003 Charter of Fundamental and Social Rights in SADC - although not legally binding - is an important human rights document that specifies the objectives laid down in Article 5 of the SADC Treaty for the employment and labour sector. Rights such as the right to freedom of association; the right to equality; the right to a safe and healthy environment; the right to remuneration; and the right to the protection of specific groups in society, such as children, the youth, the elderly, and persons with disabilities, are enshrined in the Charter of Fundamental and Social Rights in SADC.

With the 2003 Declaration on Agriculture and Food Security, the Heads of State or Government have given substantial means to some specific objectives laid down in Article 5 of the SADC Treaty, namely the promotion of sustainable and equitable economic growth and socio-economic development to ensure poverty alleviation with the ultimate objective of its eradication; the achievement of sustainable utilisation of natural resources and effective protection of the environment; and mainstreaming of gender perspectives in the process of community and nation building. By this Declaration, SADC States have committed themselves to promote agriculture as a pillar in national and regional development strategies and programmes in order to attain our short, medium, and long-term objectives, on agriculture and food security. The Declaration of Agriculture and Food Security is of specific importance for the human right to food and covers a broad range of human rights relevant issues like the increase of production of crops, livestock and fisheries, the sustainable use and management of natural resources as well as the enhancement of gender equality and human health and the mitigation of chronic diseases such as AIDS.

The 2003 Declaration on HIV and AIDS similarly strives to realise the objectives set forth in the SADC Treaty to promote sustainable and equitable economic growth and socioeconomic development that will ensure poverty alleviation; to combat HIV and AIDS and other deadly and communicable diseases; and to mainstream gender in the process of community and nation-building. The Declaration describes specific areas as urgent priorities in terms of attention and action. These areas include prevention and social mobilisation; improving care, access to counselling and testing services, treatment and support; accelerating development and mitigating the impact of HIV and AIDS; intensifying resource mobilisation; and strengthening institutional, monitoring and evaluation mechanisms.

\section{The SADC Tribunal and human rights protection}

The SADC Tribunal is the judicial institution within SADC. The establishment of the Tribunal is a major event in SADC's history as an organisation and in the development of 
its law and jurisprudence. The Tribunal was established in 1992 by Article 9 of the SADC Treaty as one of the institutions of SADC. The Summit of Heads of State or Government, which is the Supreme Policy Institution of SADC pursuant to Article 4(4) of the Protocol on the Tribunal, appointed the members of the Tribunal during its Summit in Gaborone, Botswana, on 18 August 2005. The inauguration of the Tribunal and the swearing in of its members took place on 18 November 2005 in Windhoek, Namibia, in which city Council also designated the Seat of the Tribunal to be. Article 22 of the Protocol on the Tribunal provides that for working languages of the Tribunal to be English, French and Portuguese. $^{30}$ The Tribunal began hearing cases in 2007, and has seen 17 cases filed with it to date. The SADC Protocol on the Tribunal and the Rules of Procedure thereof circumscribe the Tribunal's jurisdiction. Article 16(1) of the SADC Treaty provides for the following primary mandate:

"The Tribunal shall be constituted to ensure adherence to and the proper interpretation of the provisions of this Treaty and subsidiary instruments and to adjudicate upon such disputes as may be referred to it."

The SADC Tribunal was set up to protect the interests and rights of SADC member states and their citizens, and to develop community jurisprudence, also with regard to applicable treaties, general principles, and rules of public international law. ${ }^{31}$ Subject to the principle that local remedies first be exhausted before the Tribunal is approached, the Tribunal has the mandate to adjudicate disputes between states, and between natural and legal persons in SADC. ${ }^{32}$ Further, the Protocol states that the Tribunal has jurisdiction over all matters provided for in any other agreements that member states may conclude among themselves or within the community, and that confer jurisdiction to the Tribunal. ${ }^{33}$ In this context, the SADC Tribunal also has jurisdiction over any dispute arising from the interpretation or application of the Protocol on Gender and Development that cannot be settled amicably. ${ }^{34}$

The Tribunal was primarily set up to resolve disputes arising from closer economic and political union, rather than human rights. ${ }^{35}$ However, a recent judgement by the Tribunal

See http://www.sadc.int/tribunal/.

A..O.Chidi, Complementarity, competition or contradiction: The relationship between the African Court on Human and Peoples' Rights and regional courts in eastern and southern Africa, unpublished paper presented at the Conference of East and Southern African States on the Protocol Establishing the African Court on Human and Peoples' Rights, Gaborone, Botswana, 910 December 2003.

Article 15(2), Protocol on the Tribunal and Rules of Procedure thereof.

G. Hugo, Assessing the SADC Tribunal, unpublished article for the Institute for Security Studies, Tshwane Pretoria 2007, http://www.iss.co.za/static/templates/tmpl_html.php?node_id=2895\& slink_id=5324\&slink_type $=12 \& l i n k \_i d=24$. 
commonly known as the Campbell case, ${ }^{36}$ impressively demonstrates that the Tribunal can also be called upon to consider human rights implications of economic policies and programmes. On 11 October 2007, Mike Campbell (PVT) Limited, a Zimbabwean-registered company, instituted a case with the Tribunal to challenge the expropriation of agricultural land in Zimbabwe by that country's government. At the time, the matter was also pending in the Supreme Court of Zimbabwe. ${ }^{37}$ As a result, an application was brought in terms of Article 28 of the SADC Protocol for an interim measure to interdict the Zimbabwean Government from evicting Mike Campbell (PVT) Limited and others from the land in question until the main case had been finalised. The claimant argued that the Zimbabwean land acquisition process was racist and illegal by virtue of Article 6 of the SADC Treaty and the African Union Charter, which both outlaw arbitrary and racially motivated government action. Article 4 of the SADC Treaty stipulates that SADC and its member states are obliged, inter alia, to act in accordance with the principles of human rights, democracy and the rule of law, as well as in line with the principles of equity, balance and mutual benefit, and the peaceful settlement of disputes. According to Article 6(2) of the Treaty, -

"SADC and member states shall not discriminate against any person on grounds of gender, religion, political views, race, ethnic origin, culture or disability."

It was put forward that the constitutional amendments behind the farm seizures were contrary to SADC statutes, and that the Supreme Court of Zimbabwe had failed to rule on an application by Campbell and 74 other Zimbabwean white commercial farmers to have the race-based acquisition declared unlawful. ${ }^{38}$ The claimant alleged that he had suffered a series of invasions on his farm. The defendant state in turn argued that the land had to be given back to even out a colonial imbalance in land distribution, and that Campbell had not exhausted local remedies. The relationship between the legal regime of SADC on the one hand and Zimbabwe's national law on the other is at the core of this case. Section 23 of the Constitution of the Republic of Zimbabwe states the following:

"No law shall make any provision that is discriminatory either of itself or in its effect; and no person shall be treated in a discriminatory manner by any person acting by virtue of any written law or in the performance of the functions of any public office or any public authority."

In 2005, however, the Zimbabwean Constitution was amended. The Constitutional Amendment Act No. 17 of 2005 allows the Zimbabwean Government to seize or expropriate farmland without compensation, and bars courts from adjudicating over legal challenges filed by dispossessed and aggrieved white farmers. Section 2(2) of the Constitutional Amendment Act provides that -

Mike Campbell \& Another (PVT) Limited v The Republic of Zimbabwe SADC (T) 2/2007.

See Mike Campbell (PVT) Ltd et al. v The Minister of National Security responsible for Land, Land Reform and Resettlement and the Attorney-General. Constitutional Application No. 124/06 (unreported case: Supreme Court of Zimbabwe).

Allgemeine Zeitung, 31 March 2008: Klägerschar vervielfacht - 74 simbabwische Farmer dürfen mit Campbell Enteignung anfechten. 
“... all agricultural land - [a description of such agricultural land identified by the Government is given here] ... is acquired by and vested in the State with full title therein ...; and ... no compensation shall be payable for land referred to in paragraph (a) except for any improvements effected on such land before it was acquired."

The practical implications of the Constitutional Amendment Act resulted in farm seizures, where most of the approximately 4,000 white farmers were forcibly ejected from their properties with no compensation being paid for the land, since, according to Harare, it was stolen in the first place. The Zimbabwe Government has compensated some farmers only for developments on the land such as dams, farm buildings and other so-called improvements. ${ }^{39}$ After an interim order was issued by the Tribunal ${ }^{40}$ that Campbell should remain on his expropriated farm until the dispute in the main case had been resolved by it, the Zimbabwean Supreme Court ${ }^{41}$ (sitting as a Constitutional Court) dismissed the application by the white commercial farmers challenging the forcible seizure and expropriation of their lands without compensation. The Court ruled that $-{ }^{42}$

“... by a fundamental law, the legislature has unquestionably said that such an acquisition shall not be challenged in any court of law. There cannot be any clearer language by which the jurisdiction of the courts is excluded."

The main hearing before the SADC Tribunal was scheduled for 28 May 2008, but was postponed until 16 July 2008. In the meantime, Campbell and members of his family were brutally beaten up on their farm in Zimbabwe and allegedly forced to sign a paper declaring that they would withdraw the case from the SADC Tribunal. ${ }^{43}$ Subsequently, the applicants and other interveners in the Campbell case made an urgent application for non-compliance to the Tribunal, seeking a declaration to the effect that the respondent state was in breach and contempt of the Tribunal's orders. After hearing the urgent application, the Tribunal found that the respondent state was indeed in contempt of its orders. Consequently, and in terms of Article 32(5) of the Protocol, the Tribunal decided to report the matter to the Summit for the latter to take appropriate action.

The hearing of the Campbell case was finalised on 28 November 2008. In its final decision, the SADC Tribunal ruled in favour of the applicants Mike and William Campbell and 77 other white commercial farmers. ${ }^{45}$ In conclusion, the Tribunal held that the Repub-

Incidentally, these land reform measures have plunged Zimbabwe into severe food shortages.

On 13 December 2007.

On 22 January 2008.

See http://www.thezimbabwean.co.uk/index.php?option=com_content $\& v i e w=$ article $\& i d=13001$ : campbell-case-heads-of-argument-summary\&catid=31:top \%20zimbabwe $\% 20$ stories \&Itemid=66.

Allgemeine Zeitung, 1 July 2008: "Simbabwe: Brutaler Überfall auf Campbell - Schlägertrupps misshandeln Farmerfamilie schwer und erpressen Verzichtserklärung für Prozess am SADC Tribunal".

44

So far, no official measures have been taken by the SADC Summit in the Campbell case.

45

Mike Campbell (PVT) Limited \& Another v The Republic of Zimbabwe SADC (T) 2/2007. 
lic of Zimbabwe was in breach of its obligations under Articles 4(c) and 6(2) of the SADC Treaty, and that $-{ }^{46}$

- the applicants had been denied access to the courts in Zimbabwe

- the applicants had been discriminated against on the ground of race, and ${ }^{47}$

- fair compensation was payable to the applicants for their lands compulsorily acquired by the Republic of Zimbabwe.

Furthermore, the Tribunal directed the Republic of Zimbabwe to take all necessary measures to protect the possession, occupation and ownership of the lands of applicants who had not yet been evicted from their lands, and to pay fair compensation to those three applicants who had already been evicted from their farms. The ruling is considered to be a landmark decision which will no doubt influence the legal landscape in the SADC region. Meanwhile, the Zimbabwean Government has announced that it will not accept the judgement ${ }^{48}$ and the farm of Michael Campbell, who won the case at the SADC Tribunal was invaded. $^{49}$ This raises the question of how the SADC Tribunal's judgements are to be enforced.

The Tribunal's decisions are final and binding. ${ }^{50}$ Sanctions for non-compliance may be imposed by the Summit according to Article 33 of the SADC Treaty, and are determined on a case-by-case basis. However, no specific sanction is outlined for non-compliance with judgements issued by the SADC Tribunal. ${ }^{51}$ The Tribunal itself can only refer cases of non-

The issue of racial discrimination was decided by a majority of four to one. Judge Tshosa, in his dissenting opinion, concluded that "Amendment 17 does not discriminate against the applicants on the basis of race and therefore does not violate the respondent's obligation under Article 6(2) of the Treaty". He argued that "the target of Amendment 17 is agricultural land and not people of a particular racial group" and that - although few in number - not only white Zimbabweans had been affected by the amendment. See Mike Campbell (PVT) Limited \& Another $v$ The Republic of Zimbabwe SADC (T) 2/2007, dissenting opinion of Hon. Justice Dr Onkemetse B Tshosa.

On 28 February 2009, Zimbabwe's President Robert Mugabe said that "[T]here is no going back on the land reforms" and that "[S]ome formers went to the SADC tribunal in Namibia but that's nonsense, absolute nonsense, no one will follow that....We have courts here in this country, that can determine the rights of people. Our land issues are not subject to the SADC tribunal." See The Namibian, Mugabe says Zim land grabs will continue, 2 March 2009.

On 25 February 2009, Michael Campbell and his wife had to leave the farm in fear of their safety after a group of two vehicles led by Peter Chamada, nephew of Cabinet Minister Nathan Shamuyarira, claiming to be from the lands office came to the farm and said that they did not care about the law or the police but were taking over now. See The Namibian, Campbell flees farm invasion in Zimbabwe, 27 February 2009.

Article 16 (5) of the SADC Treaty.

51 Interestingly, a draft SADC Human Rights Charter drawn up by NGOs of SADC member states in 1996 contained a provision according to which any state "which does not comply with an order of the Court interpreting this Charter shall be suspended from SADC for the duration of its noncompliance with such order". This proposal, although it appears very effective, has, however, not been realised. See Viljoen, above Fn. 10, p. $201 \mathrm{f}$. 
compliance to the SADC Summit for the latter to take appropriate steps. Therefore, the future will show to what extent the Tribunal's judgements are taken seriously by SADC member states and by SADC itself.

Even if the Tribunal is unable to heal all domestic failures in human rights matters, since such matters are not in the focus of the institution or its mandate for regional integration, it remains to be seen whether SADC is politically and legally mature enough to apply the necessary lessons. Of significance is the fact that none of the cases heard by the Tribunal so far have dealt with disputes among member states, whereas 15 cases relate to disputes between natural/legal persons and member states, and 2 to disputes between SADC employees and SADC institutions. This interim balance shows that there is indeed a need for a supranational judicial body to decide on matters that relate to cases of imbalances between national law on the one hand and community law on the other. The Tribunal can, therefore, significantly contribute not only towards a deeper harmonisation of law and jurisprudence, but also towards a better protection of human rights at community level provided that SADC and its institutions put the necessary emphasis on the enforcement of the Tribunal's judgements.

\section{Concluding remarks}

RECs have taken into account that human rights are important on the way to realise their main objectives, commonly defined to consist in deeper regional integration aimed at enhancing economic development. The harmonisation of laws and jurisprudence is considered to be one step towards deeper regional integration. To this end, one objective must be to develop a uniform human rights standard, applicable for all member States of the single REC. At this stage, it can be concluded, that altogether, human rights protection does indeed play a vital role at sub-regional level. SADC has integrated human rights into its respective legal frameworks and the SADC Tribunal is able to accept human-rights-related cases.

One aspect that remains particularly problematic is that compliance with the SADC Tribunal's decisions depends on the political will of the Summit. When a SADC member state fails to comply with a decision of the Tribunal, such failure can again be referred to the Tribunal. If the Tribunal confirms that such failure has occurred, it can report its finding to the Summit for the latter to take the appropriate action (Tribunal Protocol, Article 32). However, the general rule is that the Summit operates on a basis of consensus. This means that also a member that has not been able to conform to the decision of the Tribunal, has to condemn its own action, if the Summit is to make any official decision on the matter.

Being a supranational institution in the region the SADC Tribunal is a part of a complex system of multi-level governance. The effectiveness of supranational action depends crucially on the strength of interdependence between the supranational and national 
levels. ${ }^{52}$ The very fact that the first cases before the SADC Tribunal deal with human rights issues and have been brought by private parties contains a particular message. This needs further exploration because it tells us other things, namely about the state of integration (or lack of it) in southern Africa, neglect of internal rule of law and the absence of more effective inter-state mechanisms for protecting human rights.

Meanwhile Zimbabwean land reform is feared to affect its neighbouring countries, especially if SADC and its institutions fail to respond to member states protecting their national sovereignty. The recent ruling of the Tribunal making the Zimbabwean land reform subject of discussion as well as the increasing number of cases pending have shown that SADC, a regional economic community is not only growing towards regional integration, but also aims at protecting human rights in the region. On 28 February 2009, Zimbabwe's President Robert Mugabe however said, that "land seizures from white farmers would continue and (...) that the SADC Tribunal had no right to rule on the land seizures". 53

The dispersion of power and the increase in integration activities leading to multiple levels of governance is, no doubt, a challenge being faced by SADC. With the Campbell case immediately the question arose how, within SADC, can state sovereignty be reconciled with the universal recognition of inalienable human rights deriving from respect for human dignity and popular sovereignty? ${ }^{54}$ How far can the universal recognition of human rights change the subjects, structures, general principles, interpretative methods and object and purpose of international law actually limit state sovereignty to renounce human rights treaties and to refuse domestic implementation of international obligations for the benefit of domestic citizens? It will be seen how the SADC Tribunal will deal with the issue of multilevel protection of individual rights and how SADC members will balance protecting their national sovereignty with their obligations towards the Regional Economic Community.

52

For comparative purposes see E. U. Petersmann, State Sovereignty, Popular Sovereignty and Individual Sovereignty: From Constitutional Nationalism to Multilevel Constitutionalism in International Economic Law? EUI LAW Working Paper No. 2006/45; http://papers.ssrn.com/sol3/ papers.cfm?abstract_id=964147. See The Namibian, 2 March 2009: "Mugabe says Zim land grabs will continue". Cf. O.C. Ruppel, Das SADC Tribunal: Eine juristische Zwischenbilanz, Allgemeine Zeitung, 5 February 2009. http://www.az.com.na/afrika/das-sadc-tribunal-eine-juristische-zwischenbilanz. 0234.php. 